\title{
Blood lead concentration and its associated factors in preschool children in eastern Iran: a cross-sectional study
}

\author{
Mahmoud Zardast ${ }^{1}$, Seyedeh Samira Khorashadi-Zadeh², Samaneh Nakhaee', Alireza Amirabadizadeh ${ }^{1,3}$ and \\ Omid Mehrpour ${ }^{1,4^{*}}$
}

\begin{abstract}
Background: Lead is a toxic metal that affects almost every organ in the body. Children are more susceptible to lead toxicity because they ingest non-food items (pica), have oral exploratory habits, absorb more substantial amounts of ingested lead compared to adults, and have a developing central nervous system. This study describes venous blood lead concentrations (BLC) in young children living in Birjand, Iran.

Methods: A cross-sectional study was performed in 2016 on children 1-7years of age who were referred to healthcare centers in Birjand City. Demographic information was obtained, and their BLC was tested using atomic absorption spectrometry (AAS).

Results: Four hundred children were tested. Their mean age was $52.37 \pm 23.77$ months; their mean BLC was $2.49 \pm$ $2.64 \mu \mathrm{g} / \mathrm{dL}$ (median $1.85 \mu \mathrm{g} / \mathrm{dL}$ ). Thirty-two (8\%) children had a BLC $>5 \mu \mathrm{g} / \mathrm{dL}$. A logistic regression model revealed that per one unit of increase in age, the chance of an elevated BLC decreased by 3\% (OR (95\%Cl): $0.97(0.96-0.99), p<0.01)$. The risks of an elevated BLC was 61\% lower in girls compared to boys (OR (95\%Cl): $0.39(0.17-0.92), p=0.03)$. Further, per one rate of increase in the BMI, the chance of an elevated BLC was higher (OR $(95 \% \mathrm{Cl}): 1.13(1.02-1.24), p=0.01)$. Children whose fathers were laborers had higher BLC than those with employee fathers $(p=0.01)$.

Conclusion: Of 400 children aged 1-7 years old living in Birjand, Iran, 8\% had elevated BLC. BLC correlated with the child 's age, gender, body mass index, and father's occupation.
\end{abstract}

Keywords: Blood lead concentration, Children, Iran, Lead toxicity

\section{Background}

Lead is a toxic environmental metal that influences almost every organ in the body [1]. Lead toxicity may happen in children because they ingest non-food items (pica), have oral exploratory habits, absorb more substantial amounts of ingested lead compared to adults, and they are more vulnerable to lead toxicity because they have a developing

\footnotetext{
* Correspondence: omid.mehrpour@yahoo.com.au

${ }^{1}$ Medical Toxicology and Drug Abuse Research Center (MTDRC), Birjand University of Medical Sciences, Birjand, Iran

${ }^{4}$ Arizona Poison \& Drug Information Center, the University of Arizona, college of pharmacy, Tucson, AZ, USA

Full list of author information is available at the end of the article
}

central nervous system [2, 3]. Lead is associated with numerous complications in children, such as neurological and neurobehavioral defects, lowered intelligence quotient (IQ), and developmental disorders [4]. Even low blood lead concentrations (BLC) can have detrimental effects on the ability of children in learning, attention, and productivity at school [5]. Blood lead concentrations have a short biological half-life that indicates the dynamic interaction among absorption, excretion, and transfer to and reabsorb from other body compartments. Thus, lead effects may not occur at well-defined blood lead concentrations [6], and there is no safety threshold for BLCs [7]. Further, the

(C) The Author(s). 2020 Open Access This article is licensed under a Creative Commons Attribution 4.0 International License, which permits use, sharing, adaptation, distribution and reproduction in any medium or format, as long as you give appropriate credit to the original author(s) and the source, provide a link to the Creative Commons licence, and indicate if changes were made. The images or other third party material in this article are included in the article's Creative Commons licence, unless indicated otherwise in a credit line to the material. If material is not included in the article's Creative Commons licence and your intended use is not permitted by statutory regulation or exceeds the permitted use, you will need to obtain permission directly from the copyright holder. To view a copy of this licence, visit http://creativecommons.org/licenses/by/4.0/ The Creative Commons Public Domain Dedication waiver (http://creativecommons.org/publicdomain/zero/1.0/) applies to the data made available in this article, unless otherwise stated in a credit line to the data. 
blood lead concentration may not precisely reflect the accumulation of tissue lead, and toxicity may happen at a low blood lead concentration. Thus, the effects of lead toxicity may have been found at blood lead concentrations below the recognized "safe" limits [6]. However, the Centers for Disease Control and Prevention (CDC) established the reference BLC as $5 \mu \mathrm{g} / \mathrm{dL}$ or less for children [8].

In 1991, CDC highly recommended screening by a blood lead test at least once for all children younger than 2 years of age [9]. Children may be exposed to lead in air, food, water, dust and debris, gasoline, dyes, and other products such as some types of traditional medicine [7]. Prior studies have shown contamination of soil, water, and some food of our region (Birjand, Iran) with different metals, including lead [10-12]. Birjand is the capital of South province in the east of Iran. It is one of the economically deprived areas of the country characterized by low income, inappropriate residential houses, lack access to clean water in some areas. Agricultural section and animal husbandry play an essential role in the economy of the province and particularly in rural regions of the province, and the life of people is dependent on it. While screening the BLC of children is practiced in other countries, no study has investigated the BLC in young children exposed to lead in the southern Khorasan province of Iran. In this study, we investigated the BLCs and its associated factors (demographic factors such as age, sex, etc.; social parameters such as occupation and education levels of parents, addiction and cigarette smoking in parents and etc.; essential trace elements such as calcium, magnesium, iron, and zinc concentrations; and hematological indices) in young children (1-7 years) living in Birjand, Iran. Also, this cross- sectional study tested the hypothesis, which children with low social status / with parental exposure more likely to have elevated lead concentrations.

\section{Methods}

In this descriptive and analytical study, 400 children with 1-7 years of age in Birjand city were studied during September to December 2016. The primary outcome was elevated blood lead concentrations $(\mathrm{BLC} \geq 5 \mu \mathrm{d} / \mathrm{dL})$ and some potential associated factors of BLCs in children. Birjand city was divided into four parts based on the four major healthcare centers in this city (the capital of southern Khorasan province in eastern Iran). Primary Health Care Centers is one of the health care networks in Iran run by the Ministry of Health and Medical Education (MOHME). These centers are a far-reaching network of public clinics that provide primary and preventive health care such as nutrition, family planning, hypertension assessment, prenatal care, immunization, and environmental monitoring. These centers are the first level of communication between families and the health system. Children in this study typically go to health centers and use health centers in the province.

A total sample size of 400 children was determined based on the study of Wang et al., With a first error level of 5\%, a standard deviation of 0.15 and accuracy of $10 \%$ of standard deviation error [13].

From each healthcare center, a health base was chosen through simple random sampling from the list of the healthcare bases covered by each center. Then, 1-to-7year-old children were ascertained through simple random sampling in line with the sample size from each base. The total number of children aged 1-7 years, covered by Birjand Health Centers, is 27,691 people. The selected number of children and the total number of children covered by each Health center of 1-8 in Birjand city were 1790(26), 2676(39), 3395 (49), 2884 (42), 5966 (86), 2799 (40), 3512 (51), 4669 (67), respectively (Fig. 1). Inclusion criteria were age 1-7 years old, consent of parents for participation in the study, subjects without identified pre-existing illness. Twenty-three parents refused to participate in the study.

Before a child was recruited into the study, informed consent was obtained from the parents. A questionnaire consisting of 22 items about demographics, as well as the risk factors of lead exposure, was then administered to parents. The obtained information was demographic factors such as age, sex, etc.; social parameters such as occupation and education levels of parents, addiction and cigarette smoking in parents, exposure to soil, and paint and etc.; essential trace elements such as calcium, magnesium, iron, and zinc concentrations; and hematological indices.

In this study, different occupations were defined as bellow:

Employee: A person who works full-time or part-time under a contract of employment, working for an organization, company, or community and has recognized rights and duties.

Laborer: a person is doing unskilled manual work for wages.

Self-employment: the state of working for oneself rather than an employer. Self-employed persons, or independent contractors, earn income by contracting with a trade or business directly. The self-employed do not receive benefits such as health insurance. Their salaries are not constant, and they have variable working hours.

\section{Laboratory measures}

5-10 mLs venous blood was taken from each child by forearm venipuncture using needles and vacuum tubes by a trained nurse; part of it was mixed with EDTA, and the other part was blended with heparin ( 20 units for each $\mathrm{ml}$ of blood) and sent to Imam Reza Hospital laboratory. The blood containing EDTA was used for 


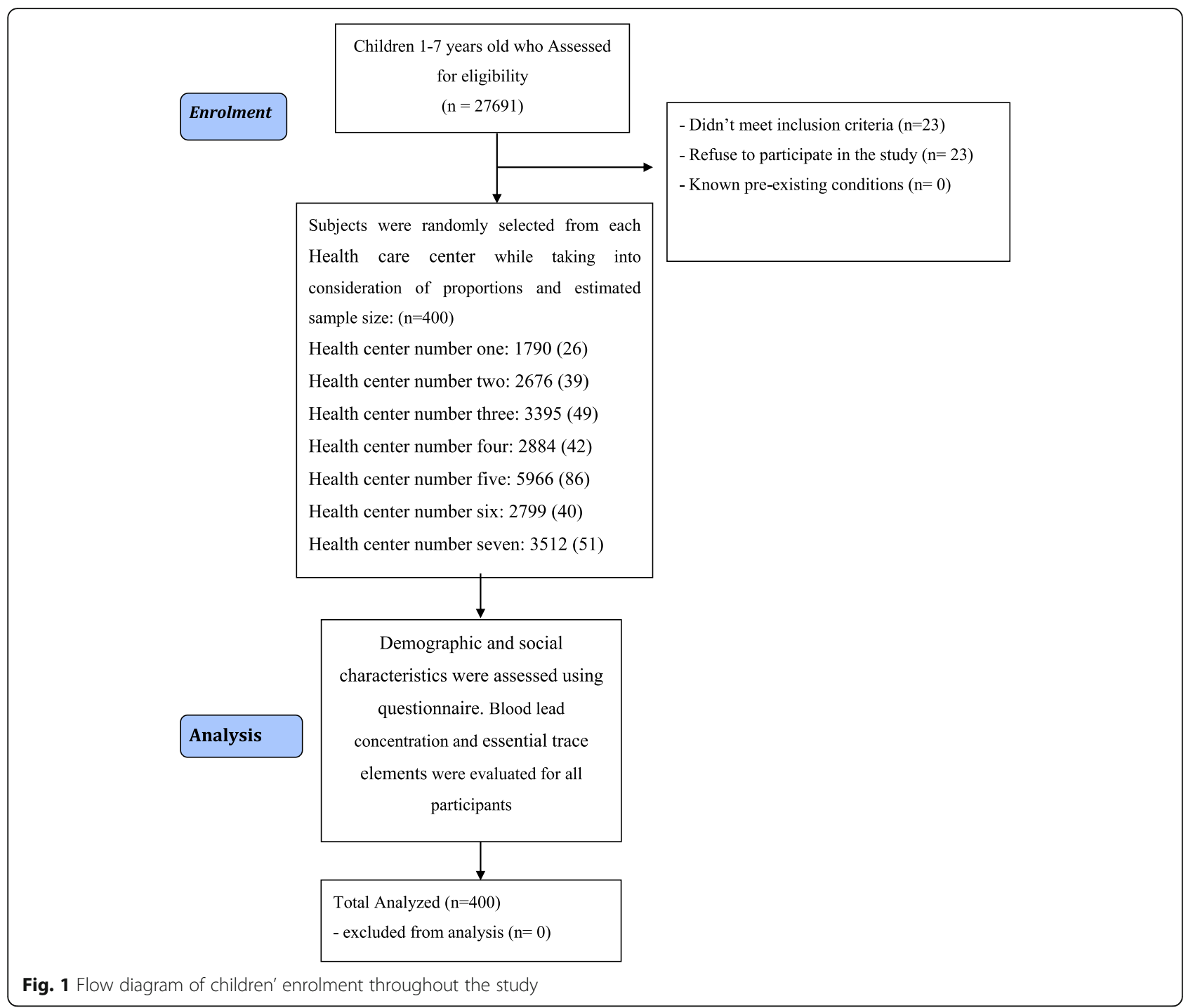

performing a complete blood count $(\mathrm{CBC})$ using the Cell Dyn Analyzer. Blood calcium, magnesium, iron, and zinc concentrations were measured using a Selectra automatic device. In order to collect the samples for lead concentrations, the free sodium heparin pink-cap 6-mL Vacuette tubes were applied. Then the samples in ice containing Styrofoam boxes were transported to the laboratory. The lead concentration in blood was measured using an atomic absorption spectrometer (Varian Co. AA500AFG, Leicester City, UK), using the standards recommended by the National Institute of Occupational Safety and Health (NIOSH) [14].

\section{Data analysis}

Data analysis was conducted through SPSS 19. Descriptive indices, including frequency, percentage, mean, and standard deviation, were calculated. Using the Kolmogorov Smirnov test, the assumption of normality of quantitative variables was tested. Mann-Whitney and Kruskal Wallis tests were used to compare BLC with demographic variables. With a logistic regression model, the factors possibly associated with BLC were inspected. Pearson correlation coefficient tests were employed to investigate the relationship between variables. An alpha level of significance was set at 0.05 .

\section{Investigational review board approval}

The research proposal was approved by the research deputy of Birjand University of Medical Sciences and by the ethics committee (ir.bums. REC.1395.131). Children with elevated lead concentrations who need treatment $(n=1)$ were followed and received free medical care.

\section{Results}

Data on 400 children aged 1-7 years in Birjand City were collected in 2016. A total of 400 subjects were 
enrolled that were included among the total children $(n=27,691)$ that routinely refer to Health Care centers. Their mean age was $52.37 \pm 23.78$ months (range: 12 to 116 months); 200 (50\%) of the children were boys. The mean BLC was $2.49 \pm 2.64 \mu \mathrm{g} / \mathrm{dL}$ (range: $0.5-29.40 \mu \mathrm{g} / \mathrm{dL}$ ) with a median of 1.85 [IQR: $1.10-2.87$ ] $\mu \mathrm{g} / \mathrm{dL}$ (Table 1). The mean BLC in males was $2.40 \pm 2.85 \mu \mathrm{g} / \mathrm{dL}$ (median 1.90 [IQR:1.10-3.20] ug/dL) and in females, it was $2.58 \pm$ $2.40 \mu \mathrm{g} / \mathrm{dL}$ (median 1.70 [IQR:1.10-2.80] $\mu \mathrm{g} / \mathrm{dL}$ ) (Table 2). The results of the Mann-Whitney test showed that the lead concentration was not significantly different between boys and girls $(\mathrm{z}=0.86, p=0.39)$. The mean lead concentration in those whose father was laborer was $3.20 \pm 3.96$ with a median of 1.80 [IQR:1.20-3.30] $\mu \mathrm{g} / \mathrm{dL}$, and in drivers, it was $1.79 \pm 0.87$ with a median of 1.70 [IQR: $1.00-2.30] \mu \mathrm{d} / \mathrm{dL}$. The results of the Kruskal Wallis test indicated that the lead concentration was not significantly different between fathers with different occupations (X2 = $3.25, p=0.66$ ). Twelve (3\%) family members had a history of drug abuse. The mean BLC in subjects whose family members had a history of drug use was $2.43 \pm 1.53 \mu \mathrm{g} / \mathrm{dL}$ (median 2.1 [IQR: 1.17-3.12] $\mu \mathrm{g} / \mathrm{dL}$ ). The mean BLC in the parents using opium was $2.95 \pm 2.10 \mu \mathrm{g} / \mathrm{dL}$ with a median of 2.45 [IQR: $1.25-3.18$ ] ug/dL, in industrial drugs of abuse, it was $1.67 \pm 0.61$ with the median of 1.65 [IQR: $1.02-2.86] \mu \mathrm{d} / \mathrm{dL}$. The mean BLCs in children exposed to paint was $2.92 \pm 3.32 \mu \mathrm{g} / \mathrm{dL}$ (median 2.10 [IQR: $1.20-3.30$ ] $\mu \mathrm{g} / \mathrm{dL}$ ) (Table 2).

In children with BLC above $5 \mu \mathrm{g} / \mathrm{dL}, 15$ (46.8\%) had anorexia, 3 (9.4\%) had persisted vomiting, 2 (6.3\%) had constipation and abdominal pain, and 8 (25\%) were asymptomatic. The results of the Chi-Square test showed that there was no significant relationship between BLC and clinical symptoms $(p=0.12)$ (Table 3).

The results of Spearman correlation coefficient tests showed no significant relationship among boys between the BLC and iron, calcium, zinc, magnesium, vitamin D,

Table 1 Frequency distribution of demographic information of children under study

\begin{tabular}{ll}
\hline Variable & Mean \pm SD/frequency (percentage) \\
\hline Age (month) & $52.37 \pm 23.78$ \\
Body mass index $\left(\mathrm{kg} / \mathrm{m}^{2}\right)$ & $15.52 \pm 4.13$ \\
Gender & \\
$\quad$ Boy & $200(50 \%)$ \\
$\quad$ Girl & $200(50 \%)$ \\
BLC & $2.49 \pm 2.64$ (range: $0.5-29.40 \mu \mathrm{g} / \mathrm{dL})$ \\
$<2.5 \mu \mathrm{g} / \mathrm{dL}$ & $273(68.3 \%)$ \\
$2.5-5 \mu \mathrm{g} / \mathrm{dL}$ & $95(23.7 \%)$ \\
$5-7.5 \mu \mathrm{g} / \mathrm{dL}$ & $17(4.2 \%)$ \\
$7.5-10 \mu \mathrm{g} / \mathrm{dL}$ & $6(1.5 \%)$ \\
$>10 \mu \mathrm{g} / \mathrm{dL}$ & $9(2.3 \%)$ \\
\hline
\end{tabular}

Table 2 Relationship between different variables and blood lead concentrations of study subjects

\begin{tabular}{|c|c|c|c|}
\hline Variable & Mean \pm SD & Median [IQR] & Test result \\
\hline \multicolumn{4}{|l|}{ Gender } \\
\hline Boy & $2.40 \pm 2.85$ & $1.90[1.10-3.20]$ & \multirow{2}{*}{$\begin{array}{l}z=0.86 \\
p=0.39\end{array}$} \\
\hline Girl & $2.58 \pm 2.40$ & $1.70[1.10-2.80]$ & \\
\hline \multicolumn{4}{|l|}{ Age } \\
\hline$\geq 72$ month & $3.03 \pm 2.28$ & $2.40[1.10-4.60]$ & \multirow{4}{*}{$\begin{array}{l}x^{2}=5.58 \\
p=0.13\end{array}$} \\
\hline 12-24 month & $2.86 \pm 4.15$ & $1.85[1.10-2.60]$ & \\
\hline 24-48 month & $2.08 \pm 1.34$ & $1.70[1.10-2.50]$ & \\
\hline 48-72 month & $2.28 \pm 2.19$ & $1.70[1.10-2.80]$ & \\
\hline \multicolumn{4}{|l|}{ Exposure to paint } \\
\hline Yes & $2.92 \pm 3.32$ & $2.10[1.20-3.30]$ & \multirow{2}{*}{$\begin{array}{l}z=1.39 \\
p=0.16\end{array}$} \\
\hline No & $2.39 \pm 2.46$ & $1.80[1.10-2.75]$ & \\
\hline \multicolumn{4}{|l|}{ Exposure to soil } \\
\hline Yes & $2.49 \pm 1.61$ & $2.20[1.10-3.25]$ & \multirow{2}{*}{$\begin{array}{l}z=1.02 \\
p=0.31\end{array}$} \\
\hline No & $2.48 \pm 2.75$ & $1.80[1.10-2.70]$ & \\
\hline \multicolumn{4}{|l|}{ Occupation of father } \\
\hline Employee & $2.18 \pm 1.33$ & $1.90[1.10-2.80]$ & \multirow{6}{*}{$\begin{array}{l}x^{2}=3.25 \\
p=0.66\end{array}$} \\
\hline Martial & $2.82 \pm 2.10$ & $2.10[1.10-4.15]$ & \\
\hline Laborer & $3.20 \pm 3.96$ & $1.80[1.20-3.30]$ & \\
\hline Repairman & $2.30 \pm 1.20$ & $2.25[1.35-2.97]$ & \\
\hline Driver & $1.79 \pm 0.87$ & $1.70[1.00-2.30]$ & \\
\hline Self-employment & $2.42 \pm 2.85$ & $1.10[1.70-1.70]$ & \\
\hline \multicolumn{4}{|c|}{ Education levels of parents } \\
\hline Primary school & $3.04 \pm 3.89$ & $1.60[1.10-3.20]$ & \multirow{4}{*}{$\begin{array}{l}x^{2}=0.87 \\
p=0.83\end{array}$} \\
\hline Middle School & $2.46 \pm 1.64$ & $2.05[1.12-3.30]$ & \\
\hline Diploma & $2.51 \pm 2.96$ & $1.80[1.10-2.75]$ & \\
\hline Bachelor & $2.16 \pm 1.43$ & $1.80[1.10-2.80]$ & \\
\hline \multicolumn{4}{|c|}{ Occupation of mother } \\
\hline Housewife & $2.45 \pm 2.64$ & $1.80[1.10-2.80]$ & \multirow{3}{*}{$\begin{array}{l}x^{2}=1.79 \\
p=0.41\end{array}$} \\
\hline Employment & $2.47 \pm 1.61$ & $1.90[1.12-3.42]$ & \\
\hline Self-employment & $3.29 \pm 4.26$ & $2.05[1.40-3.32]$ & \\
\hline \multicolumn{4}{|c|}{ Opium use in parents } \\
\hline Yes & $2.43 \pm 1.53$ & $2.10[1.17-3.12]$ & \multirow{2}{*}{$\begin{array}{l}z=0.64 \\
p=0.52\end{array}$} \\
\hline No & $2.48 \pm 2.66$ & $1.80[1.10-2.80]$ & \\
\hline \multicolumn{4}{|l|}{ Cigarette smoking } \\
\hline Yes & $2.49 \pm 2.70$ & $1.90[1.20-3.17]$ & \multirow{2}{*}{$\begin{array}{l}z=0.58 \\
p=0.56\end{array}$} \\
\hline No & $2.32 \pm 1.41$ & 1.80 [1.10-2.80] & \\
\hline
\end{tabular}

hemoglobin, hematocrit, and MCV (Fig. 2). However, in girls, there was an inverse and significant relationship between lead and iron concentrations $(r=-0.15, p=$ 0.04) (Fig. 3).

The regression model indicated that the variables of age, gender, and BMI significantly increase the probability of having $\mathrm{BLC}>5 \mu \mathrm{g} / \mathrm{dL}$. However, the job of the mother, exposure to paint or soil, parental education, 
Table 3 The association of elevated blood lead concentrations with clinical symptoms in study subjects

\begin{tabular}{lllll}
\hline Variable & Total & BLC $\geq 5$ & BLC $<5$ & Test result \\
\hline Anorexia & $100(25.0 \%)$ & $15(46.8 \%)$ & $85(23.1 \%)$ & $P=0.07$ \\
Weight Loss & $25(6.3 \%)$ & $1(3.1 \%)$ & $24(6.5 \%)$ & $P=0.10$ \\
Paleness & $11(2.7 \%)$ & $1(3.1 \%)$ & $10(2.7 \%)$ & $P=0.08$ \\
Constipation & $14(3.6 \%)$ & $2(6.3 \%)$ & $12(3.2 \%)$ & $P=0.19$ \\
Abdominal pain & $17(4.2 \%)$ & $2(6.3 \%)$ & $15(4.2 \%)$ & $P=0.06$ \\
Vomiting & $23(5.7 \%)$ & $3(9.4 \%)$ & $20(5.4 \%)$ & $P=0.25$ \\
Ataxia & $0(0 \%)$ & $0(0 \%)$ & $0(0 \%)$ & $P=0.99$ \\
Seizure & $0(0 \%)$ & $0(0 \%)$ & $0(0 \%)$ & $P=0.93$ \\
Speech defect & $0(0 \%)$ & $0(0 \%)$ & $0(0 \%)$ & $P=0.99$ \\
Memory defect & $0(0 \%)$ & $0(0 \%)$ & $0(0 \%)$ & $P=0.99$ \\
Asymptomatic & $210(52.5 \%)$ & $8(25.0 \%)$ & $202(54.9 \%)$ & $P=0.06$
\end{tabular}

history of abusing opium, and history of smoking were not significant. The results showed that per one unit of increase in age, the chance of an elevated BLC decreased by $3 \%$ (OR (95\%CI): 0.97 (0.96-0.99), $p<0.01)$. Further, per one rate of increase in the BMI, the chance of an elevated BLC was higher (OR (95\%CI): 1.13 (1.02-1.24), $p=0.01)$. In children aged 12-24 months, the chance of an elevated BLC was 3.87 times that of children older than 72 months (OR (95\%CI):3.87 (1.39-10.79), $\mathrm{p}=$ $0.01)$. The risks of an elevated BLC was $61 \%$ lower in girls compared to boys (OR (95\%CI): 0.39 (0.17-0.92), $p=0.03)$. Finally, in children whose fathers were laborers, the chance of high lead concentrations was 5.56 times higher than those whose fathers were employees $(p=0.01)$ (Table 4).

Based on the ROC curve, the age greater 34.0 months, BMI greater $16.6 \mathrm{~kg} / \mathrm{m}^{2}$ can predict high blood lead concentrations $(\geq 5 \mu \mathrm{g} / \mathrm{dL})$ (Fig. 4).

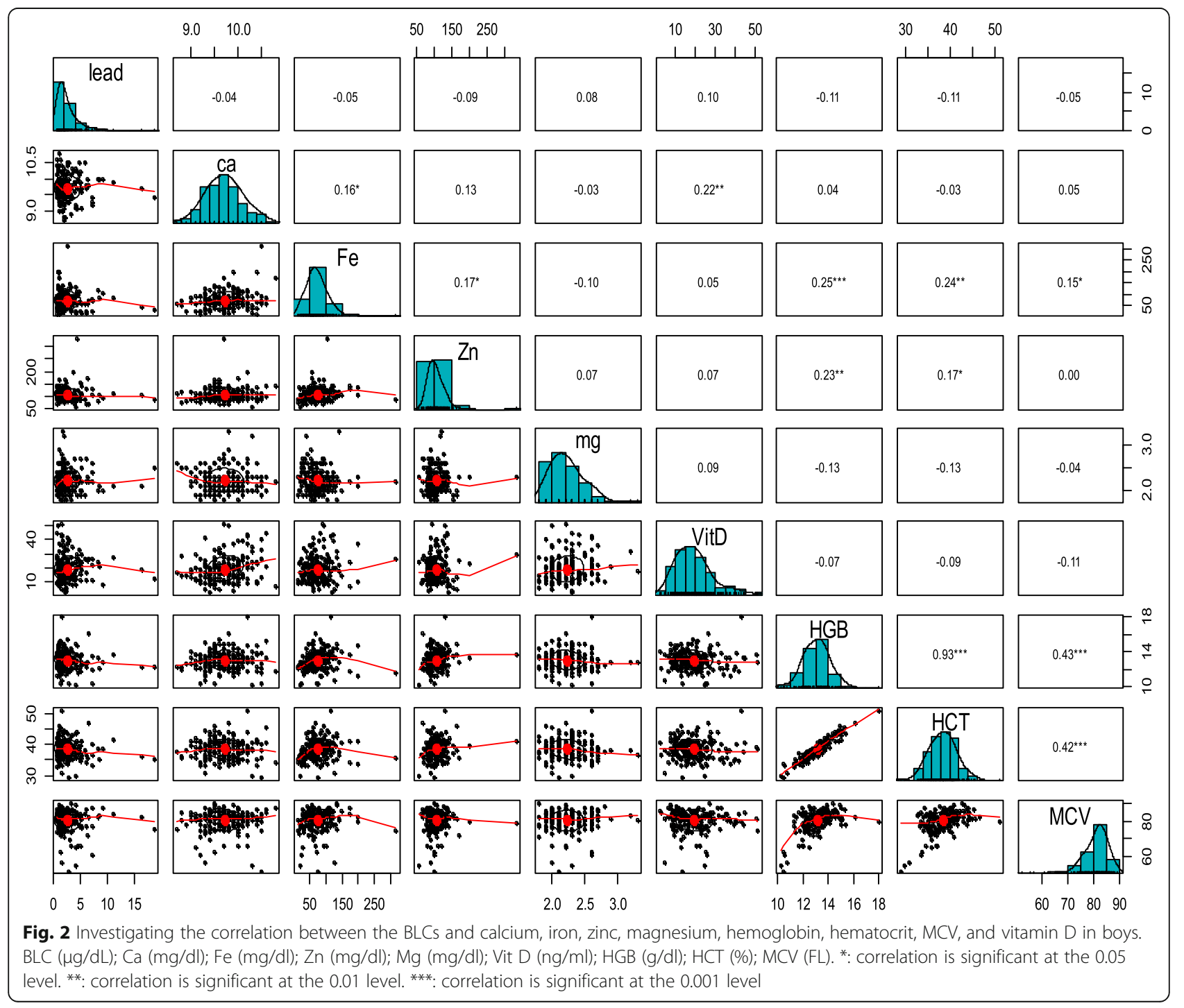




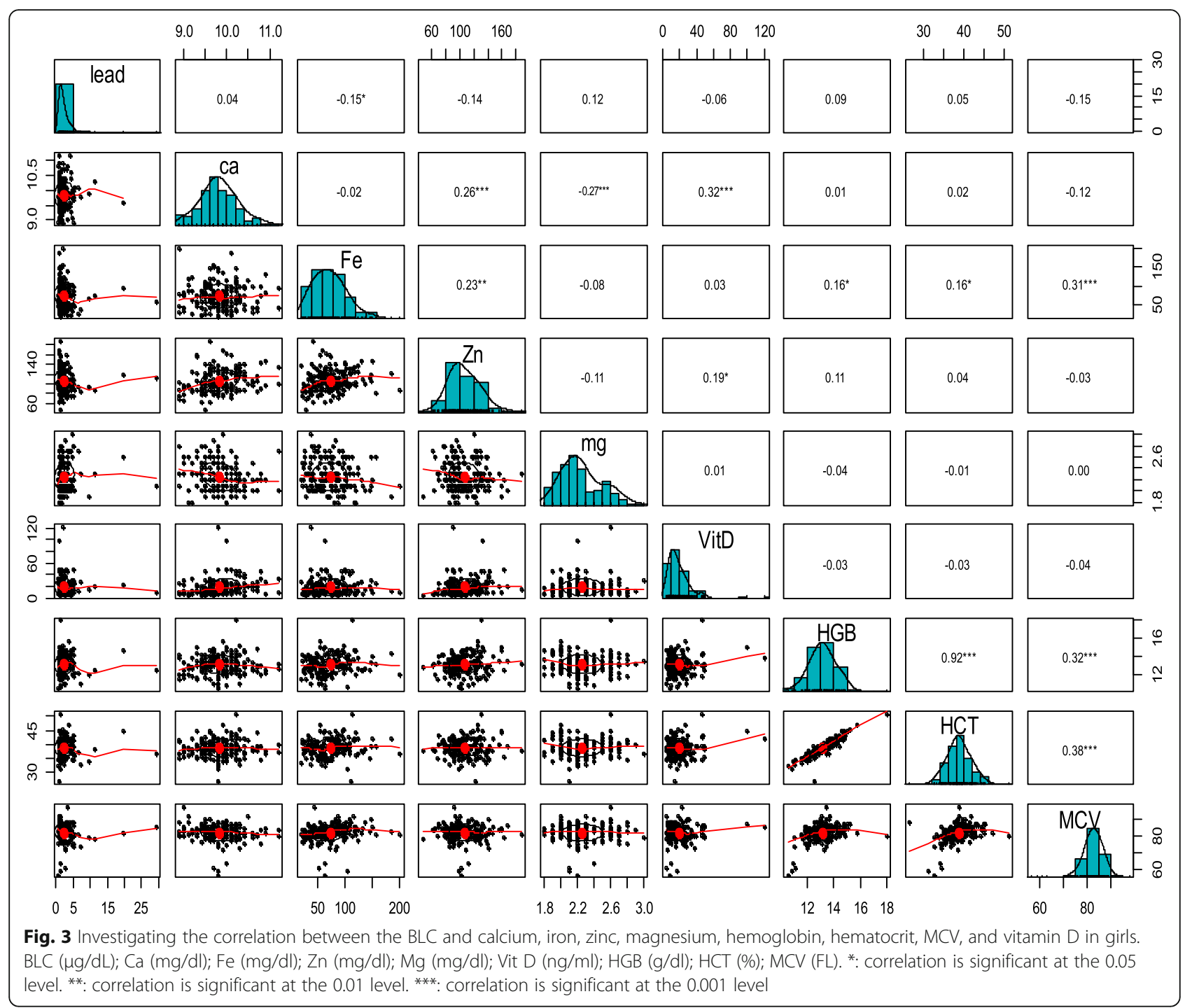

\section{Discussion}

Based on the results of this study, young age significantly increased the chance of high lead concentrations in children. In this regard, some other studies have reported similar results [15-18]. Previous studies also reported that the maximum blood lead concentration rise at the age of around 2 years [15]. These observations are not unexpected, because, at young ages, the child is in the stage of discovering the surroundings by putting their hands or other objects into the mouth (pica). This method of children's exposure has been well documented in other studies $[19,20]$. It has been found that children consume around $50 \mathrm{mg}$ of soil per day on average; if this exceeds $5 \mathrm{~g} /$ day, it is known as pica [15]. It has been reported that some children consume $25-60 \mathrm{~g} /$ day [21].

The effects of age on elevated BLC need to be more address in future studies.
In children whose fathers were laborers, the chance of elevated BLC was 5.56 times greater than that of employee fathers. Exposure to toxic materials in the workplace is a significant concern for the families of laborers employed in polluting industries [22, 23]. These individuals can carry lead debris and dust from the workplace to the house, thereby exposing the family members to lead [24]. The results of a meta-analysis indicated that around half of the children of workers exposed to lead might have BLC $\geq 10 \mu \mathrm{g} / \mathrm{dL}$, and the children of these individuals should undergo blood lead screening [22]. In the study by Chan and Morton, the BLC of children of workers contaminated with lead was higher than that of the control group. In this research, a direct relationship was found between not following professional health instructions and blood lead content [24, 25]. Nonadherence to sanitary and health-related principles by some workers laborers increases the risk of lead 
Table 4 logistic regression analysis on the association between blood lead concentrations of children and demographic variables

\begin{tabular}{|c|c|c|}
\hline Variable & OR $(95 \% \mathrm{Cl})$ & $P$-value \\
\hline Age (month) & $0.97(0.96-0.99)$ & 0.01 \\
\hline \multicolumn{3}{|l|}{ Age } \\
\hline$\geq 72$ month & Reference & \\
\hline $12-24$ month & $3.87(1.39-10.79)$ & 0.01 \\
\hline 24-48 month & $1.67(0.56-4.59)$ & 0.35 \\
\hline 48-72 month & $0.62(0.16-2.47)$ & 0.50 \\
\hline BMI $\left(\mathrm{kg} / \mathrm{m}^{2}\right)$ & $1.13(1.02-1.24)$ & 0.01 \\
\hline \multicolumn{3}{|l|}{ Gender } \\
\hline Boy & Reference & \\
\hline Girl & $0.39(0.17-0.92)$ & 0.03 \\
\hline \multicolumn{3}{|l|}{ Exposure to paint } \\
\hline No & Reference & \\
\hline Yes & $1.71(0.69-4.23)$ & 0.25 \\
\hline \multicolumn{3}{|l|}{ Exposure to soil } \\
\hline No & Reference & \\
\hline Yes & $0.53(0.12-2.33)$ & 0.40 \\
\hline \multicolumn{3}{|c|}{ Education levels of parents } \\
\hline Primary school & Reference & \\
\hline Middle School & $0.57(0.17-1.92)$ & 0.37 \\
\hline Diploma & $0.49(0.18-1.33)$ & 0.16 \\
\hline Bachelor & $0.29(0.08-1.03)$ & 0.05 \\
\hline \multicolumn{3}{|l|}{ Occupation of father } \\
\hline Employment & Reference & \\
\hline Martial & $4.64(0.87-24.51)$ & 0.07 \\
\hline Laborer & $5.56(1.44-21.40)$ & 0.01 \\
\hline Repairman & $0.03(0.001-2.65)$ & 0.97 \\
\hline Driver & $0.22(0.08-4.68)$ & 0.80 \\
\hline Self-employment & $3.26(0.89-11.88)$ & 0.07 \\
\hline \multicolumn{3}{|c|}{ Occupation of mother } \\
\hline Self-employment & Reference & \\
\hline House wife & $0.53(0.11-2.47)$ & 0.42 \\
\hline Employment & $0.78(0.13-4.73)$ & 0.78 \\
\hline \multicolumn{3}{|l|}{ Opium use in parents } \\
\hline No & Reference & \\
\hline Yes & $1.36(0.17-11.14)$ & 0.77 \\
\hline \multicolumn{3}{|c|}{ Cigarette smoking in parents } \\
\hline No & Reference & \\
\hline Yes & $1.37(0.30-6.28)$ & 0.68 \\
\hline
\end{tabular}

exposure. These workers usually neglect precautionary measures such as the use of masks, gloves, and specialized aprons; many of them do not wash their hands before meals and eat food in their workplace [26]. In many developing countries, these stores are in proximity to residential buildings, which increases the risk of exposure of others to lead. Therefore, preventive measures should be taken not only in workers of these occupations but also in the family members and children of these people.

In this study, there was an inverse and significant relationship between blood lead and iron content. Ahamed (2007) tested children with anemia exposed to lead and reported a significant negative correlation between lead and iron concentration [27]. The relationship between high BLC and iron deficiency has also been shown by Muwakkit (2008) and Hegazy (2010) [28, 29]. In these studies, the effect of lead on iron absorption from the digestive system was reported as the reason for iron deficiency. Other investigations, especially in children, have indicated that iron deficiency leads to increased lead absorption from the intestine [30,31]. Based on the results, boys did not show an iron/lead correlation, while girls with a lower prevalence of elevated blood lead concentrations showed an inverse and significant relationship between lead and iron concentrations. This point may reflect the more susceptibility of girls to lead injuries. Some studies reported that Lead-induced effects on the heme synthesis occur at lower blood lead concentrations in females than in males [32, 33]. Females may also be more prone to neurological and reproductive injuries caused by lead [34].

In this study, the mean BLC of the children was 2.49 $\mu \mathrm{g} / \mathrm{dL}$, well below the CDC reference concentration. However, $8 \%$ of studied children had an elevated BLC above $5 \mu \mathrm{g} / \mathrm{dL}$. Since this age group is most vulnerable to the adverse effects of lead on the nervous system and IQ, preventive interventions should be taken. The reason for the selection of $5 \mu \mathrm{g} / \mathrm{dl}$ as the amount of lead was that the CDC offered the reference BLC as $5 \mu \mathrm{g} / \mathrm{dL}$ or less for children [8]. Studies in other provinces and geographical regions of Tehran reported different results. A study by Daroogar et al. in 2007-2009 showed that the mean BLC of children younger than 10 years old in Tehran was $7.18 \mu \mathrm{g} / \mathrm{dL}$ [35]. Faranoush et al. (2001) performed a study in children 6-11 years old living in Semnan city. In that study, $78.8 \%$ of children had BLC > $10 \mu \mathrm{g} / \mathrm{dL}$ and $5 \%$ had $\mathrm{BLC}>20 \mu \mathrm{g} / \mathrm{dL}$ ) [36]. In these studies, the lead concentrations and the prevalence of lead poisoning were much higher than in the children described in our study. It shows these studies were performed in more contaminated locations since Tehran and Semnan are industrial cities with higher air pollution. Besides, In Iran, the leaded gasoline was extensively used until January 2002 [37] and accounted for higher BLC in those studies. Different periods separated by nine and 15 years from the current study, the different age range of studies, and greater exposure to some sources 

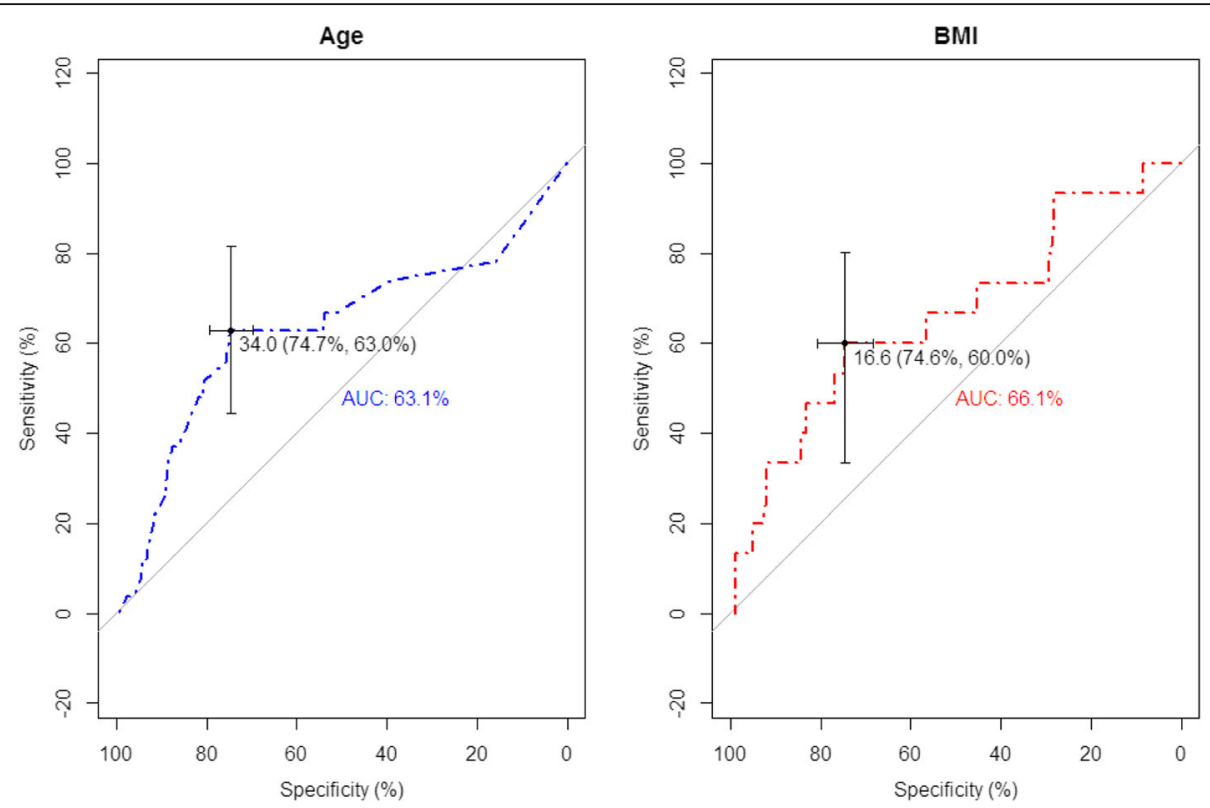

Fig. 4 ROC curve for age and BMI in predicting elevated BLC

of lead can explain the differences observed in these results. There are some changes in the use of house painter, adding lead components to gasoline, etc. elevated BLC in some participants of our study may be attributed to contamination of soil, grounded water, and some food in Birjand with different types of metals, including lead [10-12]. In this regard, previous studies have shown that the mean concentrations of lead (59.46 $\mathrm{mg} / \mathrm{kg}$ ), copper, zinc, and cadmium in the soils of the Birjand and its suburb area were higher than their concentrations in the crust of the land, indicating the presence of heavy metals in human soils. Also, another study showed that all metals concentrations in groundwater were in compliance with national and international standards and guidelines except lead $(0.023 \mathrm{mg} / \mathrm{l})$, which was higher than standard guidelines. Besides, another study evaluated heavy metal concentrations and offal samples of cows and sheep in the Birjand area, and they found that all samples were contaminated with lead, cadmium, chromium, copper, and nickel. Extensive studies worldwide have dealt with examining the BLC in children. Similar to this study, Kennedy (2016) reported that between 2013 and 2016 in Flint, Michigan, 3\% of children had BLC $>5 \mu \mathrm{g} / \mathrm{dL}$ [38]. Moreover, a national U.S. study (2016) covering the period of 2009-2015 showed that $3 \%$ of children younger than 6 years had BLC $>5 \mu \mathrm{g} / \mathrm{dL}$ [17]. In contrast, the BLC of children in Latin America and Caribbean countries between 2000 and 2014 ranged from 25 to $43.2 \mu \mathrm{g} / \mathrm{dL}$ [18], which was much higher than our study. Another study evaluated 28,427 refugee children in the U.S. between 2010 and 2014 (The top 5 overseas examination countries by arrivals were Thailand, Nepal, Malaysia, Iraq, Kenya) and reported an elevated BLC (>5 $\mu \mathrm{g} / \mathrm{dL})$ in $19.3 \%$ of cases, which was higher than our study [16].

The difference observed between different regions, and countries can be attributed to the different food, environmental conditions, and differences in the use of traditional drugs as well as cosmetics (such as Kohl), smoking, and drug abuse. All of these studies highlight the need to constantly investigating the BLC in this vulnerable population.

\section{Limitations}

In this study, we tried our best to investigate the associated factors of elevated BLCs in young children living in Birjand, Iran. But some other potential sources of lead may be involved that were not assessed in this study. This warranted further studies. Since our study investigated the risk factors and consequences concurrently because of its cross-sectional design, this prevented precise investigation of the precedence between them. Prospective studies with a larger sample size are suggested to discover potential factors of elevated blood lead concentrations among children and guarantee the generalizability of the findings to an unselected sample. Also, we did not assess the birth history of included children. To improve the accuracy of results, more extensive data sets, and enhanced data collection methods are suggested in the future. A comparative study for evaluating BLCs in different groups of children aged 1-7 years, infants and older children with considering clinical features and treatment is needed in the future. A follow-up study can be useful to evaluate the 
trend of lead concentration in the whole blood of children.

\section{Conclusion}

The mean BLC of 1-7-year-old children in Birjand city was $2.49 \mu \mathrm{g} / \mathrm{dL}$; around $8 \%$ of studied children had elevated BLC. Young age, male gender, and low BMI significantly increased the chance of an elevated BLC. These results can provide information for parents with high-risk children to have more attention and doing countermeasures. In children whose fathers were laborers, the risk of high BLC was more significant compared to those children of employee fathers, suggesting 'take-home' lead sources at work. Exposure to toxic materials in the workplace is a substantial concern for the families of laborers employed in polluting industries, needing educating workers, and conducting preventive measures. Knowing the BLC in children offers necessary information to health policymakers for public health measures, preventive interventions in the community, and health promotion of children. It also provides baseline data for future researches.

\section{Supplementary information}

Supplementary information accompanies this paper at https://doi.org/10. 1186/s12887-020-02302-7.

\section{Additional file 1.}

\section{Abbreviations}

BLC: Blood lead concentrations; AAS: Atomic absorption spectrometry; OR: Odds ratio; IQ: Intelligence quotient; CDC: Centers for Disease Control; CBC: Complete blood count; HCT: Hematocrit; HGB: Hemoglobin; MCV: Mean corpuscular volume

\section{Acknowledgments}

This paper has been the outcome of the medical degree thesis of Samira Khorashadi, performed with the financial support of Birjand University of Medical Sciences (proposal number: 923). The authors appreciate the provision of the fund as well as all participants in this research. We would also like to thank Dr. Alan Woolf, who provided valuable comments and suggestions in editing the manuscript.

\section{Authors' contributions}

MZ, SKZ, SN, AA, OM contributed to the conception, design, and preparation of the manuscript. MZ, SKZ, OM conducted the data collection and contributed to acquisition and interpretation. AA, SN, OM made substantial contributions in drafting the manuscript, and revising it critically for important intellectual content. All authors have read and approved the final version of the manuscript.

\section{Funding}

Birjand University of medical sciences funded this study. The funding body has no role in the design of the study and collection, analysis, and interpretation of data and in writing the manuscript.

\section{Availability of data and materials}

The datasets are available from the corresponding author on a formal and logical request.

\section{Ethics approval and consent to participate}

The protocol of this research was approved by the Deputy of Birjand University of medical sciences and its ethics committee (ir.bums.

REC.1395.131). The written informed consent was obtained from the parents.

\section{Consent for publication}

Not Applicable.

\section{Competing interests}

The authors have no competing interests.

\section{Author details}

${ }^{1}$ Medical Toxicology and Drug Abuse Research Center (MTDRC), Birjand University of Medical Sciences, Birjand, Iran. ${ }^{2}$ Student Research Committee, Birjand University of Medical Sciences, Birjand, Iran. ${ }^{3}$ Cardiovascular Diseases Research Center, Birjand University of Medical Sciences, Birjand, Iran. ${ }^{4}$ Arizona Poison \& Drug Information Center, the University of Arizona, college of pharmacy, Tucson, AZ, USA.

Received: 15 January 2020 Accepted: 19 August 2020

Published online: 16 September 2020

\section{References}

1. Karrari $\mathrm{P}$, Mehrpour $\mathrm{O}$, Abdollahi M. A systematic review on status of lead pollution and toxicity in Iran; Guidance for preventive measures. DARU J Pharm Sci. 2012;20(1):2.

2. Raju G, Kumar NP. Study on blood lead levels in children. Int Arch Integr Med (IAIM). 2017:4:84-93.

3. Ahamed M, Siddiqui MKJ. Environmental lead toxicity and nutritional factors. Clin Nutr. 2007;26(4):400-8.

4. Wheeler DC, Jones RM, Schootman M, Nelson EJ. Explaining variation in elevated blood lead levels among children in Minnesota using neighborhood socioeconomic variables. Sci Total Environ. 2019;650:970-7.

5. Hayatbakhsh MM, Oghabian Z, Conlon E, Nakhaee S, Amirabadizadeh AR, Zahedi MJ, Moghadam SD, Ahmadi B, Soroush S, Aaseth J. Lead poisoning among opium users in Iran: an emerging health hazard. Subst Abuse Treat Prev Policy. 2017;12(1):43.

6. Grandjean P. Widening perspectives of lead toxicity: A review of health effects of lead exposure in adults. Environ Res. 1978;17(2):303-21.

7. Moreno MA. What Parents Need to Know About the Risks of Lead Exposure for Children. JAMA Pediatr. 2018;172(2):204.

8. Centers for Disease Control Prevention. Response to the Advisory Committee on Childhood Lead Poisoning Prevention report, low level lead exposure harms children: a renewed call for primary prevention. MMWR Morb Mortal Wkly Rep. 2012;61(20):383.

9. Ettinger AS, Leonard ML, Mason J. CDC's Lead Poisoning Prevention Program: A Long-standing Responsibility and Commitment to Protect Children From Lead Exposure. J Public Health Manag Pract. 2019;25(Suppl 1 Lead Poisoning Prevention):S5.

10. Sayadi MH, Shabani M, Ahmadpour N. Pollution index and ecological risk of heavy metals in the surface soils of Amir-Abad Area in Birjand City, Iran. Health Scope. 2015;4(1).

11. Zeinali T, Salmani F, Naseri K. Dietary Intake of Cadmium, Chromium, Copper, Nickel, and Lead through the Consumption of Meat, Liver, and Kidney and Assessment of Human Health Risk in Birjand, Southeast of Iran. Biol Trace Elem Res. 2019:1-10.

12. Mansouri B, Salehi J, Etebari B, Moghaddam HK. Metal concentrations in the groundwater in Birjand flood plain, Iran. Bull Environ Contam Toxicol. 2012; 89(1):138-42.

13. Wang G, DiBari J, Bind E, Steffens AM, Mukherjee J, Azuine RE, Singh GK, Hong $X$, Ji Y, Ji H. Association between maternal exposure to lead, maternal folate status, and intergenerational risk of childhood overweight and obesity. JAMA Netw Open. 2019;2(10):e1912343.

14. Ashley K, O'Connor PF. NIOSH manual of analytical methods (NMAM), Fifth Edition National Institute for Occupational Safety and Health; 2017.

15. Yabe J, Nakayama SM, Ikenaka Y, Yohannes YB, Bortey-Sam N, Oroszlany B, Muzandu K, Choongo K, Kabalo AN, Ntapisha J. Lead poisoning in children from townships in the vicinity of a lead-zinc mine in Kabwe, Zambia. Chemosphere. 2015;119:941-7. 
16. Pezzi C, Lee D, Kennedy L, Aguirre J, Titus M, Ford R, Cochran J, Smock L, Mamo B, Urban K. Blood lead levels among resettled refugee children in select US States, 2010-2014. Pediatrics. 2019;143(5):e20182591.

17. McClure LF, Niles JK, Kaufman HW. Blood lead levels in young children: US, 2009-2015. J Pediatr. 2016;175:173-81.

18. Olympio KPK, Gonçalves CG, Salles FJ, da Silva Ferreira APS, Soares AS, Buzalaf MAR, Cardoso MRA, Bechara EJH. What are the blood lead levels of children living in Latin America and the Caribbean? Environ Int. 2017;101:46-58.

19. Lanphear BP, Roghmann KJ. Pathways of lead exposure in urban children. Environ Res. 1997;74(1):67-73.

20. Lanphear BP, Hornung R, Ho M, Howard CR, Eberly S, Knauf K. Environmental lead exposure during early childhood. J Pediatr. 2002;140(1):40-7.

21. Calabrese EJ, Stanek E, James RC, Roberts SM. Soil ingestion: a concern for acute toxicity in children. Environ Health Perspect. 1997;105(12):1354-8.

22. Roscoe RJ, Gittleman JL, Deddens JA, Petersen MR, Halperin WE. Blood lead levels among children of lead-exposed workers: A meta-analysis. Am J Ind Med. 1999:36(4):475-81.

23. Kar-Purkayastha I, Balasegaram S, Sen D, Rehman A, Dargan P, Johnston D, Raynal A, Wood D, Abrahams A, Kamanyire R. Lead: ongoing public and occupational health issues in vulnerable populations: a case study. J Public Health. 2011;34(2):176-82.

24. Morton DE, Saah AJ, Silberg SL, Owens WL, Roberts MA, Saah MD. Lead absorption in children of employees in a lead-related industry. Am J Epidemiol. 1982;115(4):549-55.

25. Chan J, Sim M, Golec R, Forbes A. Predictors of lead absorption in children of lead workers. Occup Med. 2000;50(6):398-405.

26. Dongre NN, Suryakar AN, Patil AJ, Ambekar JG, Rathi DB. Biochemical effects of lead exposure on systolic \& diastolic blood pressure, heme biosynthesis and hematological parameters in automobile workers of north karnataka (India). Indian J Clin Biochem. 2011;26(4):400-6.

27. Ahamed M, Singh S, Behari J, Kumar A, Siddiqui M. Interaction of lead with some essential trace metals in the blood of anemic children from Lucknow, India. Clin Chim Acta. 2007:377(1-2):92-7.

28. Muwakkit S, Nuwayhid I, Nabulsi M, al Hajj R, Khoury R, Mikati M, Abboud MR. Iron deficiency in young Lebanese children: association with elevated blood lead levels. J Pediatr Hematol Oncol. 2008;30(5):382-6.

29. Hegazy AA, Zaher MM, Abd el-hafez MA, Morsy AA, Saleh RA. Relation between anemia and blood levels of lead, copper, zinc and iron among children. BMC Res Notes. 2010;3(1):133.

30. Zimmermann MB, Muthayya S, Moretti D, Kurpad A, Hurrell RF. Iron fortification reduces blood lead levels in children in Bangalore, India. Pediatrics. 2006;117(6):2014-21.

31. Alabdullah H, Bareford D, Braithwaite R, Chipman K. Blood lead levels in iron-deficient and noniron-deficient adults. Int J Lab Hematol. 2005;27(2): $105-9$.

32. Roels H, Lauwerys R, Buchet J, Vrelust M-T. Response of free erythrocyte porphyrin and urinary $\delta$-aminolevulinic acid in men and women moderately exposed to lead. Int Arch Arbeitsmed. 1975;34(2):97-108.

33. Sassa S. Toxic effects of lead, with particular reference to porphyrin and heme metabolism. In: Heme and hemoproteins.: Springer; 1978. p. 333-71.

34. Zielhuis R. Second international workshop permissible levels for occupational exposure to inorganic lead. September 21-23, 1976, Coronel Laboratory, Faculty of Medicine, University of Amsterdam. Int Arch Occup Envir HIth. 1977;39(2):59-72.

35. Kamran Lalbakhsh A. The association of attention deficit hyperactivity disorder and blood lead level among children less than 10 years old referred to Tehran hospitals between 2007 and 2010. Med Sci J Islamic Azad Univ Tehran Med Branch. 2012;22(1):57-61.

36. Faranoush M, Malek M, Ghorbani R, Rahbar M, Safaei Z. Study of the blood lead levels and related factors in the 6-11 years old children in Semnan. Koomesh. 2003:4(3):79-86.

37. Nakhaee S, Amirabadizadeh A, Zarban A, Nasirizade M, Salmani Mood M, Ataei $\mathrm{H}$, Shariatmadari MR, Brent J, Mehrpour O. The reference value of blood lead level among the general adult population of eastern Iran. $J$ Environ Sci Health A. 2019:54(13):1287-92.

38. Kennedy C. Blood lead levels among children aged $<6$ years -Flint, Michigan, 2013-2016. MMWR Morb Mortal Wkly Rep. 2016;65.

\section{Publisher's Note}

Springer Nature remains neutral with regard to jurisdictional claims in published maps and institutional affiliations.

Ready to submit your research? Choose BMC and benefit from:

- fast, convenient online submission

- thorough peer review by experienced researchers in your field

- rapid publication on acceptance

- support for research data, including large and complex data types

- gold Open Access which fosters wider collaboration and increased citations

- maximum visibility for your research: over $100 \mathrm{M}$ website views per year

At BMC, research is always in progress.

Learn more biomedcentral.com/submissions 